\title{
Protection of computer-generated works in the era of new technologies
}

\author{
Ingrida Veiksa \\ Department of Law, Turiba University, Latvia
}

\begin{tabular}{|c|c|}
\hline Article Info & ABSTRACT \\
\hline Article history: & \multirow{6}{*}{$\begin{array}{l}\text { When data on works of different authors are entered into a computer system, } \\
\text { the computer analyses, synthesizes and generates a new (derived) work, if } \\
\text { such a task or algorithm is given to it. Should computer generated works be } \\
\text { considered creative and copyright protected? This issue is relevant in the } \\
\text { modern age of technology, when computer systems, the so-called artificial } \\
\text { intelligence, are becoming more independent from human influence as they } \\
\text { evolve. This review paper will search the answer of this question by critical } \\
\text { and constructive analysis of the literature, regulatory framework and case law } \\
\text { in that field. }\end{array}$} \\
\hline Received Oct 21, 2020 & \\
\hline Revised Dec 7, 2020 & \\
\hline Accepted Feb 13, 2021 & \\
\hline Keywords: & \\
\hline Artificial intelligence & \\
\hline
\end{tabular}

This is an open access article under the CC BY-SA license.

Computer system

Copyright

Creativity \begin{abstract}
the computer analyses, synthesizes and generates a new (derived) work, if such a task or algorithm is given to it. Should computer generated works be intelligence, are becoming more independent from human influence as they and constructive analysis of the literature, regulatory framework and case law
\end{abstract}

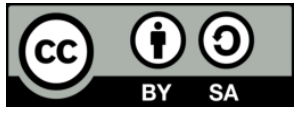

\section{Corresponding Author:}

\author{
Ingrida Veiksa \\ Department of Law \\ Turiba University \\ Latvia \\ Email: ingrida.veiksa@gmail.com
}

\section{INTRODUCTION}

In recent years, computer systems have been able to generate literary and artistic works that are difficult to distinguish from man-made works. Increasingly, these computer-generated works are so successful that collectors want to buy them and museums want to include them in their collections. Computer systems already write news, poetry, chat, and compose music. The originality and quality of such works has raised the issue of copyright in them, highlighting two main issues: firstly, whether such works are to be regarded as copyrighted works and, secondly, who is entitled to copyright. These issues are becoming more and more relevant in today's age of technology, when computer systems, the so-called artificial intelligence (AI), are becoming more and more independent of human influence.

At present, the legal regulation of various countries holds that the precondition for copyright protection is human creative activity. However, there is no consensus on who is considered to be the authorwho programs, enters data, trains, assigns tasks or selects results? From an economic point of view, investment in $\mathrm{HE}$ is significant, especially in job creation. One of the aims of intellectual property is to promote the creation of works. It is therefore important that the legal regime applicable to works created by $\mathrm{HE}$ encourages these investments [1]. Options for dealing with computer-generated works and suggestions on how best to place them in copyright are discussed [2]. However, the rights granted to the copyright owner are not absolute, as they include the condition of fair use of the work to promote knowledge and lawful use, which is neither copyright infringement nor plagiarism [3].

The aim of this study is to find a solution who would be recognized as the author of a work created by the computer system. The problem arises when we try to find out which of the people has done enough for 
his work to be considered creative and for him to gain the status of an author. How to evaluate it? In most countries, human intellectual activity is a prerequisite for copyright protection. However, in most national laws it is not defined which person is to be recognized as the author.

What is artificial intelligence? It is not easy to determine exactly when a system becomes a set of components with artificial intelligence. The border is wide and not so easy to find. One of the methods defined in the 1960s is the Turing test. It states that: if a computer can imitate human reactions over a period of time, i.e. react as a human would do, it can be said that a computer has artificial intelligence. In [4] There are several stages in the creative process: preparation, maturation, clarity (followed by the creative process) and testing [5]. One of the main questions of the theory has been the so-called 4P creativity model. According to this model, creativity can be viewed from four different perspectives: product, process, person and press of the environment. Human creativity can be stimulated by these components [6]. What are the stages and incentives of a computer system-generated work process?

Research question: Should works created by artificial intelligence (computer systems) be considered creative and protected by copyright?

Some authors believe that assigning copyright to an algorithm does not further the objectives of copyright law; it also does not fit well into its incentive structure [7]. Some authors conclude [8] that the current regime is woefully insufficient to cope with the use of increasingly intuitive artificial intelligence systems in the production of such works. It is believed that human strength is his creativity. People cannot let creativity get out of control; it is their monopoly and it must be taken care of by all nations. Without privacy, there is no creativity, and the individual must feel free to create [9]. If creativity is the main criterion for creating a work, then there should be criteria for assessing the characteristics of creativity.

Very little scientific research has been done on this topic, but its importance is growing with the rapid development of technology. Therefore, the author offers a review of the literature, legal framework and case law, in which the answers to the research question will be sought.

The author of this article is convinced that works created by artificial intelligence must be protected by copyright, and such protection must not differ from the usual (traditional) protection of authors' works. Creativity means - having the skill and ability to produce something new, especially a work of art [10]. Only humans can be recognized as the author of a work, and no computer or algorithm can be identified as the copyright owner. Originality is an important criterion in creating a job. Provided that the requirements for human participation and originals are met, the protection systems for works created by computer systems must be the same as those created by humans.

\section{RESEARCH METHOD}

Research question - should computer generated works be considered creative and copyright protected? In order to find the answer to the research question, both international and national law were studied, case law from different countries was used, materials of international conferences as well as information accessible on the Internet on possible protection of copyright works created by computer systems or "artificial intelligence" were examined. The research used an analytical method to investigate the works of various researchers on the need for protection of computer-generated works, the regulatory framework and court practice in this field, as well as a grammatical, systemic, teleological, and historical interpretation of legal norms to assess the inadequacy of existing legal norms and propose the necessary amendments in legislative enactments. The author of this article will look at the concept of artificial intelligence mainly from the viewpoint of of law, less will analyze its theoretical framework and will not touch on research in the field of engineering at all. The scientific literature in the field of law will be examined more than in the field of social and technical sciences. However, it will not be possible to study the relationship between artificial intelligence and the law without examining its theoretical framework and knowledge of creativity.

\section{RESULTS AND DISCUSSION}

\subsection{Discussion}

In this section, are explained the results of research and given discussion. The discussion is made in three sub-chapters. The literature sources in which authors analyze issues of artificial intelligence and copyright matters will be considered first. The second subchapter will analyze and compare both international and national legislation to find out the views of legislators on the protection of intellectual property. The third subchapter will look at the rulings of different courts to understand how law enforcement institutiohns are coping with challenges dictated by technological developments. Some results are presented in figures and formulas that make the reader understand the problem easily. 


\subsubsection{Literature review}

Increasingly, digitally generated content that we use on a daily basis is created without human intervention or with very little impact on it. This content is usually attached by claims of copyright. However, depending on the copyright regulations of each country, the treatment of such works may be either strictly regulated or uncertain. The options for how computer-generated works may be treated and suggestions for their best placement in the copyright system are discussed [2]. Several authors have already performed a thorough literature analysis [11], reviewing the literature on the use of intellectual property analysis methods, i.e., artificial intelligence, machine learning, deep learning, and artificial neural network methods for IP data analysis. The study concludes that there has been a growing interest in this area in recent years, as evidenced by the increase in the number of articles and the increase in the total number of citations of the papers. A study has been carried out [12] on the process by which artificial intelligence and blockchain were used to manage the IP rights lifecycle, resulting in 3D print data files (Lego-type bricks). Such data files may be subject to various intellectual property rights, including copyrights, trademarks, and patents. As such, they offer uses that could be of interest to many IP practitioners. From a legal point of view, the notion of creativity is one of the means of legal techniques to distinguish copyrighted works from non-copyrighted works [13]. However, this criterion is relevant only in the event of a dispute, for example in determining whether a person is to be considered as a co-author of the work or merely a technical performer [14].

According to the dictionary, a computer system is a full configuration of a computer and its peripheral devices (including drives, monitors, and various input/output devices) that collectively process data under the control of an operating system [15]. The computer system, using data input and in accordance with set tasks (algorithm), or so-called "artificial intelligence", creates new works, influenced by the works previously created by various authors. The data and algorithm are provided to the computer by a human being, but the computer analyses, groups, and creates the new work. If a computer is "influenced" by human work that is input into its program, can the computer-generated output be considered a creative original work? The Tilde dictionary explains the concepts of creativity, creation and intelligence as follows: Creativity is defined as the ability to create new material or spiritual values or to arrange ideas and realities in a specific relationship, to express original, interesting thoughts or approaches. Creation, on the other hand, is a human activity that produces qualitatively new, original material and spiritual values or ideas. The concept of intellect is interpreted as the structure of intellectual abilities, which provides the ability of the mind to perceive features of objects and phenomena, their interrelationships, as well as solve new tasks in a new set of circumstances by using the results of cognition [16]. All these features are unquestionably human, and neither animal nor machine (computing system) could compete with man regarding the possession of these qualities. Artificial intelligence methods are used to solve technical tasks such as development of computerbased training systems and expert systems, but the algorithm is a goal oriented set of sequential actions used to obtain a result from the given input data through a number of finite elementary actions or steps [15].

A view expressed in literature is that works created by artificial intelligence should not be protected by copyright; they could possibly be protected as related rights or perhaps under competition law. Granting such rights could have a negative impact on people who would no longer be interested in making efforts to create new works as they could easily be created by computer systems [17]. Another view expressed is that such works should be protected by copyright, but only for humans, not for the computer or algorithm. Copyright specific incentives and grounds for the existence of copyright law are when copyright is granted to a person, whether programmer, user, data owner or combination of them. Otherwise, human programmers and users will not be incentivized to create, improve, and use "creative" AI. Thus, even if or when AI does reach a point where it could truly be developing "original intellectual conceptions" ofitsown, granting copyright to algorithm would not further the purposes of copyright law; nor does it fit well with its incentive structure [7]. AI has direct connection with intellectual skills, the ability tounderstand, learn and make autonomous decisions independent of the will of the developer or user. The main difference of AI and human intelligence is its artificial (synthetic) nature [18]. Some authors conclude [8] that the current regime is woefully inadequate to deal with the growing use of more and more intuitive artificial intelligence systems in the production of such works. It considers the respective claims of interested parties to such rights before moving on to a consideration of the creation of a new legal personality to which such rights could be granted to resolve the difficulties inherent in the current system.

Artificial intelligence not only generates new works, but its help is used in the study process to detect plagiarism. In Latvia a number of higher education institutions have developed their own internal legislation governing the detection and prevention of plagiarism. In recent years, various computer programs have been used to detect plagiarism, helping to identify borrowed or stolen text in a new document, if any, and also counting the percentage of similarities between the suspected text and the huge anti-plagiarism software database. Plagiarism software does not give a conclusion about plagiarism at work. It only checks the work against the huge but limited database that is available to it. If the program suspects that the new 
(suspected) script is similar to or matches any of the database sources, it shows an overlap with the original source. The database usually contains an extremely large number of web pages: both current and archived from the Internet, and a collection of documents. Although its database contains thousands of magazines, ebooks, and web pages, it may not contain everything ever written. Therefore, some plagiarized texts are certainly not detected [19]. Plagiarism most often involves rewording, as well as semantic and lexical changes that are very difficult to detect with common tools. We can find two documents that share the same word or the same sentences but they are not semantically similar, in addition to that we can lose the semantic aspect when the documents are treating via a list of sentences or words. Therefore a research has been done how to detect plagiarism using a deep learning, method [20]. In civic, professional and extracurricular life, students need to be able to promote their writing, and part of this work increasingly involves effective orientation in the material, technological and cultural systems through which their writings travel [21]. In such a situation, the use of artificial intelligence is useful and invaluable.

There are several offers on the Internet to check for the presence of plagiarism in the authors' works. Sometimes they are available for free, sometimes only for a fee. However, great care must be taken to publish (upload) your work in these tools if there is no assurance that the data will be used properly and lawfully. It has been heard that these tools are designed to produce a large volume of works by authors that can then be used in a variety of ways. Therefore, before returning the results of one's spiritual activity (author's work) for use, one must be absolutely certain that it will be used in accordance with the author's interests. One of the tools for detecting plagiarism, the origin and legal use of which is in doubt, is a unified computerized plagiarism control system created jointly by Latvian higher education institutions, in which the works can be compared with the works developed by students in 16 Latvian Universities.

\subsubsection{Legal acts}

Research on AI requires a general and comprehensive approach. Intellectual property is protected in many countries administrative, civil and criminal proceedings. Each of them performs its function, each individually conveying a partial vision of this legal regime. To understand the concept and its rules, it is necessary to analyze the whole [22]. Legislators in different countries have different approaches to drafting legislation. In Japan, for example, there are plans to develop a legal framework for the protection of copyright on novels, music and other works created by artificial intelligence. The Japanese government considers [23] that legislative changes are needed to protect artificial intelligence from unauthorized use and to allow the developer of the AI system to receive fair compensation.

In the European Union only narrow exceptions to copyright are possible in the regulation of copyright, which can be applied only in special situations. There is no wide scope to adapt to contemporary art law movements and situations not foreseen by the legislator. The legal systems of the European Union and Latvia would need a more flexible approach to copyright solutions in the long run. This would ensure a fair application of restrictions, balancing the interests of authors and the public. Studies [24] show the importance of seeking a solution to the existing legal framework using existing copyright exceptions, such as some of the "open" rules in the Berne Convention [25] and the InfoSoc Directive [26] "three - step" test. This would provide flexibility while respecting the balance between copyright and public rights. The Latvian copyright law [27] stipulates that the author of a work is a natural person whose creative activity has resulted in a specific work. This is an axiom, because only a natural person has the ability to think and act creatively, only he has the intellect. Copyright law also states that copyright belongs to the author as soon as the work is created. This means that the original intellectual property rights, including copyright, arise at the time the work is created and that the original subject can only be a natural person, i.e. a human being. Copyright law also stipulates that derivative works must be protected, regardless of whether the works from which they are derived can be protected by copyright. This means that works created by computer systems must also retain the basis of copyright protection - creativity and originality. An original work is a work that has never been created anywhere in the world. Originality must be a precondition for protection, including in cases where the work is considered to be derived from work created by another person.

In the UK, the legislator has already gone a step further and envisages that jobs can also be generated by computer systems. The law determines who owns the authorship of work: "In the case of a literary, dramatic, musical or artistic work which is computergenerated, the author shall be taken to be the person by whom the arrangements necessary for the creation of the work are undertaken" [28]. Although the regulation contained in the law does not provide a full understanding of what is considered to be "necessary arrangements", it does provide an opportunity for copyright protection for works created by AI. New Zealand copyright law also contains similar provisions which stipulate that the author of a literary, dramatic, musical or artistic work who is computerized is the person who must arrange the creation of the work [29]. The European Union on 2019 has adopted a new digital single market directive [30], which amends the 2001 InfoSoc [26] Directive. It contains many innovations on works created and made available in the digital 
environment, but it does not address the issue of copyright ownership of works generated by artificial intelligence.

\subsubsection{Case law}

In US courts, there have been several copyright disputes over whether an author may be a person other than a human being. The female monkey Naruto took a series of selfies from a camera left unattended by the wildlife photographer David John Slater that the photographer found suitable enough to be published in magazines and books, as well as on several websites. PETA, an animal protection association, filed a lawsuit as a "close friend of Naruto", claiming copyright infringement. However, a US court ruled that it was not possible to file a lawsuit on behalf of the monkey and therefore the monkey could not own the rights to those photographs [31].

A recent court ruling in China on copyright ownership where a human had not participated in the creation of the work. The law office of Beijing films released a report on big data analysis on its website that focused on court cases in the Beijing film industry. The next day, Baidu Netcom published an article without permission in the Baijiahao newspaper, removing the introduction, lines and charts. The law office filed a lawsuit against Baidu Netcom, claiming that it had infringed on their copyrights, distribution and protection against distortion. Baidu Netcom claimed that the report contained text and infographics, both of which were automatically embedded in a computer program owned by Wolters Kluwer. The Law Office had neither researched nor searched for the data to obtain it-was it generated by a computer program that created graphs and the analysis. Therefore there were no grounds for objection against the modification of the report as it is not an author's work. The court ruled that a computer system, which is usually considered a machine with software, is not eligible to be the author of the works, and thus the works created by it are not protected by copyright law. The work according to copyright laws must meet two requirements: it must be original and man-made [32]. The court stated that while a software developer is not eligible for the copyright of the work, he can still seek protection of his rights in some other reasonable way. However, the court did not answer the question as to exactly what rights the software developer might have. If ownership of such works were to be granted to a software developer, it would be detrimental to cultural and knowledge communication [33].

Disputes regarding copyright ownership by humans and understanding of creativity can also be found in the European Union. For example, in the CJEU Painer case (C 145/10) [34], the creative requirement for photography was formulated-[a work] is the intellectual creation of its author, if it reflects his/her personality, if the author while creating the work can realise his/her creative abilities, freely and creatively choose - the background, the subject's pose or lighting, the framing, the angle of view, and the atmosphere created. Thus, through these various choices, the author of a photograph may give the work created a "personal character" [35]. The InfoSoc Directive 19] does not give an explanation of what is authorship. This is explained in the Painer case by Advocate General Trstenjak of the EU Court of Justice, stating clearly (section 121) that only human creations are therefore protected, which can also include those for which the person employs a technical aid, such as a camera [36].

There are not many disputes about the ownership of copyright in Latvian case law, but there are some findings. For example, authorship from the copyright aspect is understood as a person's participation and creative intellectual contribution to the creation of a work sufficient enough to be recognized as the author of the work 37], and the existence of the work already confirms the creative activity of producing the work, granting the author personal and economic rights [38].

\subsection{Results}

\subsubsection{Works generated by computer systems}

A machine is capable of analysing a huge amount of data and building on this experience create various objects, integrating them in a variety of combinations according to the given tasks or algorithm. There are severalexamples of computer programsworldwide, which by analysing and combining the data entered in them, are capable of producing amazing original works. A computer can write a poem, edit photos, and even compose music [39].

In 2018, a painting called "Portrait of Edmond Belamy" as illustrated in [40, Figure 1], was auctioned by the auction house Christie'sand could be sold for $\$ 7,000$ to $\$ 10,000$, according to experts. First the computer analysed a data set of 15,000 portraits painted between the 14th to the 20th century. Then the first part of the algorithm created a portrait based on the data obtained, while the second part tried to find the difference between the man-made artwork and the one generated by the algorithm. "It may not have been painted by a man in a powdered wig, but it is exactly the kind of artwork we have been selling for 250 years,"said Richard Lloyd, who organised the sale [41]. A label stating the origin of the work is placed at the bottom of the painting, and the author's "signature" is the algorithm as illustrated in [40, Figure 2]. 
The Dutch Museum houses a computer-generated portrait of "The Next Rembrandt", as illustrated in [42, Figure 3], which was created based on thousands of data entered from the works of the 17th century Dutch artist. The computer system, imitating Rembrandt's style, produced a portrait that could be considered as created by the artist himself [43].

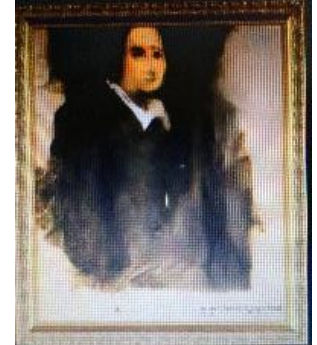

$\min _{G} \max _{D} \mathbb{E}_{x}[\log (D(x))]+\mathbb{E}_{z}[\log (1-D(G(z)))]$

Figure 2. The algebraic formula of the Artificial Intelligence's algorithm is written in place of the signature

Figure 1. Portrait of Edmond

Belamy, 2018, created by generative adversarial network (GAN). Artificial intelligence generated work, based on portraits created by artists in the past

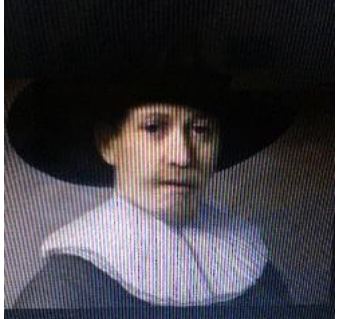

Figure 3. A work created by artificial intelligence, imitating Rembrandt's portrait style

Google has made a major contribution to the development of artificial intelligence by supporting and funding several programs and projects. A program for writing local news articles: journalists enter stories from open national databases, including government and municipal websites, and create "detailed story templates" on topics such as crime, health and employment. Multiple versions of the story are created with the help of a special computer program, which "increases the mass localization of news content" [44]. A system that writes poetry-a computer system was taught in the Gutenberg project to understand the language. The system programmers read the system an introductory sentence and instructed it to continue the sentence. Analysing the texts, the computer was able to determine which author had written the sentence and was able to continue writing text in a similar style; the chat bot that frightened its creators - the computer system learned the art of conversation by analysing millions of film scenarios, enabling it to rethink the meaning of life, blood colour, morals, and even be angry at its human inquisitor. When asked what the meaning of life was, the chat bot answered: "To live forever" [45].

Computer system can create music [46], after listening to recordings. The project team entered hundreds of Eurovision songs-melodies and lyrics-into a neural network. The algorithms then produced thousands of new tunes and poems, some of which were carefully selected and "strung" in a song called "Blue Jeans and Bloody Tears" [47], a duet of unhappy love between Izhar Cohen (Israel's first Eurovision winner in 1978) and a computer which was written and composed by a computer. The song was produced by Avshalom Ariel, one of the creators of TOY. Although the Eurovision Song Contest took place this year remotely due to the threat posed by COVID-19, the Australian team used AI to create a song called "Beautiful the World" [48]. They "taught" pop music to a computer by entering data (music and lyrics) from previous Eurovision song contests, and added some Australian voices-koalas, kookaburras and Tasmanian devil audio. The result was an attractive pop song created by a computer system (although people intervened to arrange the words more logically) [29].

In Japan, a computer-generated novel entered the first round of the science fiction award [49]. A group of Irish musicians introduced around 23,000 Irish folk songs into the computer system and now the systemcan now compose Irish folk music [50] while various computer programs have competed with players of certain games (chess, Go) and have won the games [4]. The originality and quality of such works has raised the issue of copyright, highlighting two main questions, firstly, whether such works qualify as copyright works and, secondly, who is entitled to the copyright [51].

\subsubsection{Authors of works generated by computer systems}

As computer systems become more intelligent, they begin to generate works. Can these works be protected by copyright and should they be? How should the interests of the computer system owner be protected? In most countries, human intellectual activity is a prerequisite for copyright protection. Allocating copyright to the algorithm would normally result in ownership of the copyright by the company or individual 
who owns the AI itself, since the owner of the AI would also own any of the AI's "possessions." In many cases, the owner would be the company that employed the programmer(s) who created the algorithm (as a work made for hire, or otherwise assigned through employment agreements or other contracts). Given that allocating the copyright in the output in this manner also distorts the incentives for the human creators who could be influenced instead, it does not make any practical sense to go down this road [7]. Consequently, it is understandable that the author can only be a human being, and neither the computer nor the algorithm have the capacity to think creatively, and therefore cannot be the subject of copyright. However, given the large number of people involved in the creation of computer programmed works in the age of new technologies, there must be a clear legal framework as to which of these people is eligible for authorship. Is it the person who programs, trains or runs the computer program, the person who gives the program a task, the one who decides to create the work, or someone else? The existing legal framework does not currently answer these questions. In the current legal framework, if a monkey cannot be recognised as an author, that doesn't give much hope to AI either. The question, however, remains: with such a speed of developments in the field of AI and with its confidently entering into the art world, will our copyright laws ever catch up? [52]. Although there have been a number of legislative initiatives in Australia over the last 25 years, including recommendations to adopt a UK-style approach, Australia's position remains unchanged. Unfortunately, for the time being, the works created by AI are looking for an author [29].

Despite the lack of a direct definition of "natural person" in the Latvian copyright law, in accordance with the general understanding of the civil law and in accordance with the Merriam-Webster Law Dictionary and practice, "natural person" means a "human" [53]. The Chinese court's findings in the Baidu Netcom case [26] are consistent with the resolution adopted in September 2019 at the international association for the protection of intellectual property (AIPPI) world congress on rights holders of computer-based work. The AIPPI ruled that works created by computer systems (artificial intelligence) are entitled to copyright protection only if the creation of the work was done by a human being: if the person inserted data into the computer system or gave the system a task (programmed the algorithm). However, works created in such way do not qualify for copyright protection simply because a person has created a computer system, or simply because a person has chosen (selected) one or more works from among newly created works. Such activities shall not be considered as creative activities [54]. Many of these problems have not as yet materialized but come they will. As intellectual property rights play a greater part in commerce and become more valuable we shall see many interesting and novel attacks on the ownership of such rights in infringement cases [55]. As a general principle, we believe that no moral rights should be granted in AIgenerated content, based on existing laws and principles. While there is extensive debate on the possibility of AI having its own legal personality and thus the possibility of AI being capable of moral rights, much of this discussion is centered on AI liability-which has different considerations vis-à-vis moral rights [56]. AI challenges need to be approached from an interdisciplinary perspective.

Technology, ethics and rights are inevitable components of this debate. It is not easy to combine each of these dimensions of AI but only a serious and continuous commitment to mutual understanding between them would allow us to respond to these challenges [ff22]. The idea that the protection of authors of works generated by computer systems should not differ from that of usual (traditional) protection for works of authors is gradually being crystallized in literature and in legislation and case law as well.The only area where the works created by man directly or through a computer system could differ would be the scope of moral or personal rights. Authors of computer-generated works currently have the same personal rights under copyright law as authors of all other works. However, there is a growing resonance about the reduction of the scope of personal rights for certain categories of authors (authors of computer programs, databases, audiovisual and architectural works, as well as for authors of works commissioned by employers and generated by computer systems) where a large number of persons or technology was widely used in the creation of the such work. For authors of these works, the level of individual rights should be reduced to the threshold set by the Berne Conventions [25]: to claim authorship of the work and the right to object to any mutilation, deformation or other modification of, or other derogatory action in relation to, the work that would be prejudicial to the author's honour or reputation. This section has been misinterpreted in the copyright law by dividing it into two parts. The Berne Convention provides for the possibility of invoking personal rights against modification only if it undermines the honour or reputation of the author. In other cases, modification is the economic right of the author and may be transferred to another person.

\section{CONCLUSION}

As a result of the research, it is concluded that there is no common understanding in the world about the copyright holders of works generated by artificial intelligence. Only a few countries have incorporated this regulation into their national laws. Some countries are going to do that. However, in the vast majority of 
countries, there is a view that no special regulation is needed. However, the prevailing view is that computergenerated works should be protected, as they are backed by a number of creative personalities whose work needs to be appreciated. The answer to the research question is that: works created by a computer system must be protected by copyright! Every creative person deserves protection for the creative contribution that was given to creating a work through a computer system. However, the protection of authors of computergenerated works must not differ from the usual (traditional) copyright protection. Only human beings can be recognized as the author of a work (including a computer-generated work), and no animal, computer, or algorithm can be identified as the copyright owner. The protection of such works must not be subject to any conditions (requirements, term of protection, and restrictions or exceptions.) other than the protection of man-made works. A computer-generated work can only be considered protected if the person who entered the data or gave the system a task participated in the creation of this work. Computer system activities that resulted in the creation of an object without human intervention cannot be considered work. In order to incorporate these conclusions into Latvian legislation, many amendments to the copyright law would not be necessary, as the copyright of works created by computer systems should not differ much from the copyright of ordinary works. However, some clarifications would be desirable. First, the list of protected derivative works should include works created by humans through a computer system. Secondly, it should be established that the authors of these works are the persons who entered the data into the computer system and gave it a task. However, persons who at the end of the process simply selected one or more works (outputs) generated by the computer system cannot be recognized as the authors of the work. The rules on the moral rights of authors should also be supplemented by setting only the minimum personal rights required by the Berne Convention for authors of computer-generated works. They have the right to claim authorship and to object to any distortion to the work, which would be prejudicial to his honor or reputation. This article analyzes legislation, case law and research on copyright in artificial intelligence works and shows a lack of consensus on this issue. Therefore, a further in-depth analysis of national case law is needed, comparing the national laws of different countries, creating the best possible model that could be incorporated into national laws. The protection of works generated by artificial intelligence is becoming increasingly important for the economic development of each country, and we must be prepared to face these technological challenges.

\section{REFERENCES}

[1] J. OSHA, "Study Question: Copyright in artificially generated works." Study Guidelines. AIPPI World Congress London, 2019. [Online]. Available: https://aippi.org/event/2019-aippi-world-congress-london/

[2] M. Perry and T. Margoni, "From music tracks to Google maps: Who owns computer-generated works?,"Computer Law \& Security Review, vol. 26, no. 6, pp. 621-629, Elsevier Ltd, 2010, https://doi.org/10.1016/j.clsr.2010.09.005.

[3] M. P. Satijaand and D. Martínez-Ávila, "Plagiarism: An essay in terminology," DESIDOC: Journal of Library \& Information Technology, vol. 39, no. 2, pp. 87-93, 2019, DOI: 10.14429/djlit.39.2.13937.

[4] M. Mierina, "What is artificial intelligence?," Tilde. Accessed on: Dec. 04, 2020. [Online]. Available: https://www.tilde.lv/tildes-sarunas/kas-ir-maksligais-intelekts.

[5] Tilde, Term "creation," Letonika.lv. Accessed on: Dec. 04, 2020. [Online]. Available: https://www.letonika.lv/groups/default.aspx?r=1107\&q=jaunrade\&id=2061047\&g=1

[6] T. Min and A. Gruszka, "The 4P's Creativity Model and its application in different fields," Handbook of the management of creativity and innovation: Theory and practice. World Scientific Press. Accessed on: Dec. 04, 2020. [Online].

Available: https://www.researchgate.net/publication/316644392_The_4P\%27s_Creativity_Model_and_its_application_in_diff erent_fields

[7] S.F. Hedrick, "I think, therefore I create: claiming copyright in the outputs of algorithms," Journal of Intellectual Property \& Entertainment Law, vol. 8, no. 2, pp. 324-375, 2019. Accessed on: Dec. 04, 2020. [Online]. Available: https://jipel.law.nyu.edu/vol-8-no-2-1-hedrick/.

[8] C.R.Davies, "An evolutionary step in intellectual property rights - Artificial intelligence and intellectual property," Computer Law \& Security Review, vol. 27, no. 6, pp. 601-619, 2011. Accessed on: Dec. 04, 2020. [Online]. Available: https://doi.org/10.1016/j.clsr.2011.09.006.

[9] I. Ziemele, "Artificial intelligence and human rights," 16th Seminar on Constitutional Law Policy. Ratnieki, pp. 2226 July, 2019. [Online]. Available: http://at.gov.lv/lv/jaunumi/par-notikumiem/konstitucionalas-tiesibpolitikasseminara-diskute-par-labu-likumdosanu-un-modernajam-tehnologijam-9677.

[10] S. Wehmeier, et al., "Oxford Advanced Learners Dictionary," 7th edition, 2005. Oxford University Press..[Online]. Available: https://www.academia.edu/27987826/Oxford_Advanced_Learners_Dictionary_7th_Edition.

[11] L. Aristodemou and F. Tietze, "The state-of-the-art on Intellectual Property Analytics (IPA): A literature review on artificial intelligence, machine learning and deep learning methods for analysing intellectual property (IP) data," World Patent Information, vol. 55, pp. 37-51. 2018. Accessed on: Dec. 25, 2020. [Online]. Available: https://doi.org/10.1016/j.wpi.2018.07.002.

[12] S. Ragot, A. Rey and R. Shafai, "IP lifecycle management using blockchain and machine learning: Application to 3D printing datafiles," World Patent Information, vol. 62, 101966, 2020, Accessed on: Dec. 14, 2020. [Online]. Available: https://doi.org/10.1016/j.wpi.2020.101966. 
[13] M. Grudulis, "Introduction to copyright," Latvijas Vēstnesis, Page. 54, 2006. [Online]. Available: https://books.google.lv/books/about/Ievads_autorties\%C4\%ABb\%C4\%81s.html?id=r4gLGQAACAAJ\&redir_esc= y.

[14] M. Krumins and J. Rozenfelds, "Comments on the Constitution of the Republic of Latvia," Chapter VIII. Fundamental Human Rights, Latvijas Vēstnesis. Page. 689, 2011. [Online]. Available: https://lv.lv/?menu=pakalpojumi\&sid=27\&id=299.

[15] Tilde, Term "computer system, algorithm," Letonika.lv. Accessed on: Dec. 04, 2020. [Online]. Available: https://www.letonika.lv/groups/default.aspx?r=1107\&q=datorsist\%C4\%93ma\&id=2072182\&g=1; https://www.letonika.lv/groups/default.aspx?q=algoritms\&s=0\&g=1\&r=1107.

[16] Tilde, Term "intelect", Letonika.lv. Accessed on: Dec. 04, 2020. [Online]. Available: https://www.letonika.lv/groups/default.aspx?r=10621049\&q=intelekts\&cid=771346\&g=2.

[17] A. Strowel, "Redefining copyright law in the framework of artificial intelligence technologies," Annual Conference on EU Copyright Law 2019. Trier, 2019. [Online]. Available: https://www.era.int/upload/dokumente/21872.pdf.

[18] P. Cerka, J. Grigiene and G. Sirbikyte, "Is it possible to grant legal personality to artificial intelligence software systems?," Computer Law \& Security Review, vol. 33, pp. 685-699, 2017. http://dx.doi.org/10.1016/j.clsr.2017.03.022.

[19] M.P. Satija and D. Martínez-Ávila, "Plagiarism: An essay in terminology," DESIDOC: Journal of Library \& Information Technology, vol. 39, no. 2, 2019, DOI: https://doi.org/10.14429/djlit.39.2.13937.

[20] El M. Hambi and F. Benabbou, "A deep learning based technique for plagiarism detection: a comparative study," IAES International Journal of Artificial Intelligence (IJ-AI), vol. 9, no. 1, pp. 81-90, 2020, DOI: http://doi.org/10.11591/ijai.v9.i1.pp81-90.

[21] W.E. Dustin, "Circulation Gatekeepers: Unbundling the Platform Politics of YouTube's Content ID," Computers and Composition, vol. 47, pp 61-74, 2018. DOI: https://doi.org/10.1016/j.compcom.2017.12.001.

[22] M. Robles Carrillo, "Artificial intelligence: From ethics to law," Telecommunications Policy, vol. 44, no. 6, 2020. DOI: https://doi.org/10.1016/j.telpol.2020.101937.

[23] Japan moves to protect 'copyrights' of AI creations. KYODO, the Japan Times, 10.05. 2016. [Online]. Available:Retrieved from: https://www.japantimes.co.jp/news/2016/05/10/national/japan-moves-protectcopyrights-ai-creations/\#.X193ex8zbmg

[24] R. Zigurs, “The concept of appropriation in the art law," Jurista vārds, 1 August, 2017/No. 32 (986), Accessed on: Dec. 04, 2020. [Online]. Available: https://juristavards.lv/doc/271110-piesavinasanas-jedziens-makslas-tiesibas/.

[25] Berne Convention for the Protection of Literary and Artistic works. Signed in Berne on 9 September 1886. Published: Latvijas Vēstnesis, 21/02, 13.06.43.

[26] Directive 2001/29/EC of the European Parliament and of the Council of 22 May 2001 on the harmonization of certain aspects of copyright and related rights in the information society. Published: Oficiālais Vèstnesis, L 167, pp. 10-19, 22.06.2001.

[27] Copyright Law of the Republic of Latvia, Latvijas Vēstnesis (2000, no 148/150) [Online]. Available: https://likumi.lv/ta/en/en/id/5138.

[28] Copyright, Desings and Patents Act, UK. Adopted: November 15, 1988, Accessed on: Dec. 06, 2020. [Online]. Available: https://wipolex.wipo.int/en/text/474030.

[29] R. Hoad and S. Martine, "The authorless song: Artificial intelligence and Australia's copyright law regime," Clayton Utz., 14 MAY 2020. Accessed on: Dec. 26, 2020. [Online]. Available: https://www.claytonutz.com/knowledge/2020/may/the-authorless-song-artificial-intelligence-and-australiascopyright-law-regime.

[30] Directive (EU) 2019/790 of the European Parliament and of the Council of 17 April 2019 on copyright and related rights in the Digital Single Market and amending Directives 96/9/EC and 2001/29/EC, OJ L 130, pp. 92-125, 17.5.2019 [Online]. Available: https://eur-lex.europa.eu/eli/dir/2019/790/oj.

[31] Naruto v. Slater, No. 16-15469 (9th Cir. 2018). Accessed on: Dec. 04, 2020. [Online]. Available:https://law.justia.com/cases/federal/appellate-courts/ca9/16-15469/16-15469-2018-04-23.html.

[32] W. Xin, "Copyright concerning computer-generated content put to test," China Daily 07/18/2019 page17. Accessed on: Dec. 04, 2020. [Online]. Available:http://www.chinadaily.com.cn/cndy/2019-07/18/content_37492759.htm.

[33] Y. Ma and G. Yang, "Are AI-related works copyrightable?," Managing Intellectual Property (www.managingip.com), July/August 2019, issue 282, pp. 51-53. Accessed on: Dec. 04, 2020. [Online]. Available:https://www.managingip.com/article/b1kbm0h1qkbbp1/are-ai-related-works-copyrightable.

[34] CJEU. Eva-Maria Painer v Standard Verlags GmbH and Others. Case C-145/10. European Court Reports 2011 00000 [Online]. Available: https://eur-lex.europa.eu/legal-content/en/ALL/?uri=CELEX\%3A62010CJ0145.

[35] Judgment of the Court of Justice of the European Union (CJEU) 1 December 2011. Case C 145/10 Eva-Maria Painer v Standard Verlags GmbH (Painer). [Online]. Available: https://eur-lex.europa.eu/legalcontent/en/ALL/?uri=CELEX\%3A62010CJ0145.

[36] Opinion of Advocate General Trstenjak delivered on 12 April 2011, Case C 145/10. [Online]. Available: https://eur-lex.europa.eu/legal-content/EN/TXT/?uri=CELEX\%3A62010CC0145.

[37] Judgment of the Ventspils Court of the Republic of Latvia of 30.10.2014 in the case Nr. 140017314. Accessed on: Dec. 04, 2020. [Online]. Available: file:///C:/Users/User/Downloads/Anonimizets_nolemums_191964.pdf.

[38] Judgment of the Department of Civil Cases of the Senate of the Supreme Court of the Republic of Latvia of 19 April 2006 Nr. SKC - 266. [Online]. Available: http://at.gov.lv/en/court-proceedings-in-the-supreme-court/archiveof-case-law-decisions. 
[39] A. Guadamuz, "Artificial intelligence and copyright", October 2017. University of Sussex, United Kingdom. $\begin{array}{lllll}\text { Accessed } & \text { on: Dec. } 2020 . & \text { [Online]. Available: }\end{array}$ http://www.wipo.int/wipo_magazine/en/2017/05/article_0003.html.

[40] Christie's, "Is artificial intelligence set to become art's next medium?," Accessed on: Dec. 04, 2020. [Online]. Available: https://www.christies.com/features/A-collaboration-between-two-artists-one-human-one-a-machine9332-1.aspx.

[41] Satori, "For the first time, a painting created by artificial intelligence is auctioned," 25.10.2018. Satori. Accessed on: Dec. 04, 2020. [Online]. Available: https://www.satori.lv/article/pirmo-reizi-izsola-maksliga-intelekta-raditugleznu.

[42] New Rembrandt' to be unveiled in Amsterdam. The Guardian. Accessed on: Dec. 04, 2020. [Online]. Available: https://www.theguardian.com/artanddesign/2016/apr/05/new-rembrandt-to-be-unveiled-in-amsterdam.

[43] The Next Rembrandt. Accessed on: Dec. 04, 2020. [Video file]. Available: https://www.youtube.com/watch?v=IuygOYZ1Ngo.

[44] Press Association wins Google grant to run news service written by computers," The Guardian. Accessed on: Dec. 04, 2020. [Online]. Available: https://www.theguardian.com/technology/2017/jul/06/press-association-winsgoogle-grant-to-run-news-service-written-by-computers.

[45] M. Burgess, "Google's AI has written some amazingly mournful poetry," 16.05.2016. Accessed on: Dec. 04, 2020. [Online]. Available: http://www.wired.co.uk/article/google-artificial-intelligence-poetry.

[46] D. Coldewey, "Google's WaveNet uses neural nets to generate eerily convincing speech and music," @techcrunch, September 9, 2016. Accessed on: Dec. 04, 2020. [Online]. Available: https://techcrunch.com/2016/09/09/googleswavenet-uses-neural-nets-to-generate-eerily-convincing-speech-and-music/.

[47] Eurovision song created by Artificial Intelligence: Blue Jeans and Bloody Tears,” Accessed on: Dec. 04, 2020. [Video file]. Available: https://www.youtube.com/watch?v=4MKAf6YX_7M.

[48] Eurovision 2020 AI song contest champion: Beautiful the World. Accessed on: Dec. 26, 2020. [Video file]. https://www.youtube.com/watch?v=sAzULywAHUM.

[49] C. Olewitz, "Japanese AI program just wrote a short novel, and it almost won a literary prize," Digital Trends. Accessed on: Dec. 04, 2020. [Online]. Available: https://www.digitaltrends.com/cool-tech/japanese-ai-writesnovel-passes-first-round-nationanl-literary-prize/.

[50] The Bottomless Tune Box. Accessed on: Dec. 04, 2020. [Video file]. Available: https://www.youtube.com/watch?v=YedcDs_-Zdc.

[51] V. Kalnina "Who owns the copyright to the work created by the artificial intelligence," Jurista vārds. 1 August, 2017/NR. 32 (986). [Online]. Available:Retrieved from: https://juristavards.lv/doc/271112-kam-pienakasautortiesibas-par-maksliga-intelekta-raditu-darbu/.

[52] M. Boicova-Wynants "Can copyright laws ever catch up with the new world where AI created art gets auctioned at Christie's?," Artlaw, Accessed on: Dec. 04, 2020. [Online]. Available: https://artlaw.club/lv/maksla-untiesibas/neskaidras-radosuma-robezas-vai-autortiesibu-likumi-kadreiz-pagus-pielagoties-jaunajai-pasaulei-kurmaksliga-intelekta-radita-glezna-tiek-izsolita-christie-s-eng.

[53] Legal Definition of natural person (noun): a human being as distinguished from a person (as a corporation) created by operation of law. Merriam-Webster Law Dictionary. Accessed on: Dec. 04, 2020. [Online]. Available: https://www.merriam-webster.com/legal/natural_person.

[54] AIPPI "Study Question Copyright in artificially generated works. Resolution," AIPPI World Congress 2019London, September 18, 2019. [Online]. Available: https://aippi.org/event/2019-aippi-world-congress-london/

[55] C. R. Davies, "An evolutionary step in intellectual property rights-Artificial intelligence and intellectual property," Computer Law \& Security Review, vol. 27, no. 6, pp. 601-619, 2011, DOI: https://doi.org/10.1016/j.clsr.2011.09.006.

[56] M. Miernicki and I. Ng (Huang Ying), "Artificial intelligence and moral rights," AI \& Soc., 2020, DOI: https://doi.org/10.1007/s00146-020-01027-6.

\section{BIOGRAPHY OF AUTHOR}

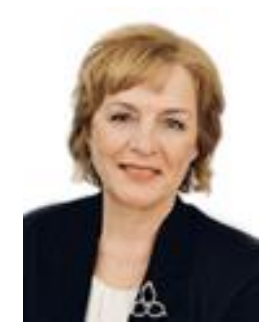

Dr. iur, Ingrida Veiksa, earned a Doctoral Degree in Law Sciences in Latvian University at 2010. The author's major field of study is intellectual property, main research interests is copyright and education. Ms Veiksa is Head of Law Department, Professor and the Director of Program of Law Sciences at the Turiba University in Riga, Latvia, where she lectures intellectual property law. From 1994 to 2009, Ms Veiksa was Legal Adviser to the Latvian public broadcaster Latvian Television. Ingrida Veiksa was admitted to the Latvian Bar Association at 2010, since 2011 she is an expert in the Law Science of the Latvian Council of Science. She is the author of textbooks and several publications, has regularly participated in international scientific conferences with reports. Member of working groups for the drafting of intellectual property and broadcasting law in Latvia; member of Latvia Media Institution and Consultative Committee of the National Broadcasting Council. 